\title{
Anxiolytic-like and sedative effects of Kyllinga brevifolia in mice
}

\section{María del Carmen Hellión-Ibarrola, "Yenny Montalbetti, Olga Y. Heinichen, María L. Kennedy, Miguel A. Campuzano, Derlis A. Ibarrola}

Departamento de Farmacología, Facultad de Ciencias Químicas. Universidad Nacional de Asunción. San Lorenzo, Paraguay.
Revista Brasileira de Farmacognosia Brazilian Journal of Pharmacognosy 22(6): 1323-1329, Nov./Dec. 2012

\begin{abstract}
Kyllinga brevifolia Rottb., Cyperaceae, rhizomes have been widely used in the Paraguayan folk medicine as digestive, diuretic, sedative, tonic, antispasmodic and sudorific. The purpose of this study is to characterize the putative sedative, anxiolytic effects of the crude hydro-ethanolic extract (CEKb) and fractions of the rhizome of $K$. brevifolia, in male mice. The behaviour of mice was assessed in the open field, hole board, rota-rod and elevated plus-maze (EPM) test. Oral treatment with single doses of 10,100 and $1000 \mathrm{mg} / \mathrm{kg}$ of CEKb and $10 \mathrm{mg} / \mathrm{kg}$ of ethyl acetate fraction (KbF-ethyl-ac) increased the duration of the sleeping time induced by pentobarbital. Oral administration of 1,10 and $100 \mathrm{mg} / \mathrm{kg}$ of CEKb and $0.1,1$ and $10 \mathrm{mg} / \mathrm{kg}$ of KbFethyl-ac also significantly increased the time-spent and arm entries into open arms of the elevated plus maze (EPM) versus control group. These findings indicate that $K$. brevifolia exerts a weak sedative and an interesting anxiolytic-like effect in mice and suggest its potential usefulness for the treatment of anxiety in humans.
\end{abstract}

Received 26 Apr 2012

Accepted 27 Jun 2012

Available online 20 Sep 2012

Keywords: anxiolytic elevated plus-maze hole board Kyllinga brevifolia open field

ISSN 0102-695X http://dx.doi.org/10.1590/S0102$695 \times 2012005000112$

\section{Introduction}

Generalized Anxiety Disorder is one of the most frequent (up to $10 \%$ ) of all mental disorders among older age groups (Lieb et al., 2005). Anxiety is a cardinal symptom of many medical psychiatric disorders and an almost inevitable component of many medical and surgical conditions. Indeed, it is an universal human emotion, closely allied with appropriate fear, and often serving psychobiologically adaptive purposes (Ross, 2006). In general, anxiety disorders are treated with medication, specific types of psychotherapy, or both. Benzodiazepines (BDZ) are considered as safe drugs and are widely prescribed for their anxiolytic, muscle relaxant, sedative-hypnotic and anticonvulsant actions. However, they may produce side effects, such as sedation and myorelaxation that are considered as unwanted effects in an anxiolytic drugs (Woods et al., 1992).

The development of novel anxiolytic drugs is a very active field of research in academia and the pharmaceutical industry. Although alternative treatments are increasingly being used to alleviate affective disorders, strong evidences recommending the use of herbal medicines for several illnesses are still scarce (Ernst, 2000).

Kyllinga brevifolia Rottb., Cyperaceae, rhizomes are used in Paraguayan traditional medicine as a refreshing beverage, and is claimed to possess digestive, diuretic, sedative, tonic, antispasmodic and sudorific properties (Basualdo \& Zardini, 1995). Gatti (1985) mentioned the use of the aromatic leaves and rhizomes as carminative and digestive. In a previous work in mice, we have found that $K$. brevifolia induces a stimulating effect on the intestinal transit, increases the sleeping time induced by barbiturate and none adverse effects (Hellión-Ibarrola et al., 1999). Concerning its chemical composition, in the rhizome was revealed the presence of flavonoid glycosides kaempferol 3-O- $\beta$ apiosyl-(1-2)- $\beta$-glucoside, isorhamnetin 3-O- $\beta$-apiosyl$(1-2)-\beta$-glucoside and quercetintriglycoside (quercetin 3-O- $\beta$-apiofuranosyl-(1-2)- $\beta$-glucopyranoside $7-O-\alpha-$ rhamnopyranoside) (Apers et al., 2002).

Pharmacological activity of Kyllinga and Cyperus species has been investigated previously, and it was demonstrated hepatoprotective, sedative and anticonvulsant effects (Rakotonirina et al., 2001; Ha et al., 2002; Bum et al., 2004; Pal et al., 2009; Somasundaram et al., 2010). However, despite the popular use of $K$. brevifolia, its psychopharmacological properties remain unclear.

The present study was performed to evaluate the influence of the crude extract of the rhizomes of $K$. brevifolia $(\mathrm{CEKb})$ and their fractions on a behavioral screening in mice, through the following test: sleeping time induced by sodium pentobarbital, motor 
coordination (rota-rod), exploratory and ethological behaviour (open field and hole board tests) and the exploration on an elevated plus-maze test (anxiolytic or anxiogenic-like actions). Our results indicate that $\mathrm{CEKb}$ and ethyl-acetate fraction exert anxiolytic-like effect and contribute to the scientific knowledge of this potential phytotherapeutics resource to ameliorate anxiety symptoms.

\section{Materials and Methods}

\section{Plant material and extraction}

Kyllinga brevifolia Rottb. (Cyperus brevifolius (Rottb.) Endl. ex Hassk.), Cyperaceae, known as kapi-i katí (guaraní name meaning smelling grass), were collected in Paraguarí Department, Paraguay, in February 1991 and identified by Isabel Basualdo. A voucher specimen is deposited at the herbarium of Facultad de Ciencias Químicas, Universidad Nacional de Asunción under the number Basualdo 2900. Fresh rhizomes were air-dried and ground, yielding $459.5 \mathrm{~g}$ of powder. The powder was extracted three times with a mixture of ethanol:water $(70: 30)$ by a conventional reflux method for $1 \mathrm{~h}$, the filtered hydro-ethanolic extracts were mixed and evaporated under reduced pressure. The concentrated extract was frozen and finally freeze-dried to yield $31 \mathrm{~g}$ of lyophilized crude rhizome extract (CEKb). A sample of $5.2 \mathrm{~g}$ of CEKb was suspended in $500 \mathrm{~mL}$ of deionized water and successively extracted with hexane, chloroform and ethyl acetate (3x $500 \mathrm{~mL}$ each). $n$-Hexane (KbF-hex) and chloroform (KbF-Chlo) fractions were dried with anhydrous sodium sulphate, filtered and evaporated under reduced pressure at $40{ }^{\circ} \mathrm{C}$. Ethyl acetate fraction (KbF-ethyl-ac) was concentrated under reduced pressure and the aqueous solution was filtered yielding a soluble fraction (KbF-aq), which was freeze-dried.

\section{Animals}

Swiss albino male mice, weighing 20-30 g were used in all experiments. Animals were kept on a $12 \mathrm{~h}$ light-dark cycle, at a constant room temperature $\left(23-25^{\circ} \mathrm{C}\right)$, in humidity controlled environment (50$60 \%$ ) with free access to food and water except during the experiments. All experiments were conducted in accordance with international standards of animal welfare and the experimental protocols were approved by the Bioethical Committee of the Facultad de Ciencias Químicas (FCQ-2004/01). The minimum number of animals and the duration of observation required to obtain consistent data were used, each animal was used only once. Behavioral experiments were conducted from 9:00 am to 2:00 $\mathrm{pm}$.

\section{Drugs}

Diazepam(Valium) from Roche Pharmaceutical Co., Ltd. (Argentine), pentobarbital (Nembutal) from Abbott (Japan) sodium sulphate and sodium chloride was obtained from Sigma Chemical Company (St. Louis, MO, USA), ethanol, chloroform, ethyl acetate, $n$-hexane, tween 80 and propylenglycol were purchased locally, all solvents were distilled before use.

\section{Pentobarbital-induced hypnosis}

Mice were distributed into groups of twelve animals and one hour after oral administration of saline $(0.1 \mathrm{~mL} / 10 \mathrm{~g}$ body weight), $\mathrm{CEKb}(1,10,100$ and 1000 $\mathrm{mg} / \mathrm{kg}$ ), KbF-hex, KbF-Chlo, KbF-aq and KbF-ethylac $(0.1,1$ and $10 \mathrm{mg} / \mathrm{kg})$ each animal was injected with sodium pentobarbital ( $35 \mathrm{mg} / \mathrm{kg}$, i.p.). Diazepam $(0.5 \mathrm{mg} / \mathrm{kg}$ i.p.) was used as positive control (standard anxiolytic/hypno-sedative drug) in this assay. The latency to the loss of righting reflex (induction time in seconds) and the time required to recover righting reflex or awakening (sleeping time in min) were registered for each animal as previously described (Carlini, 1973).

\section{Open field test}

Open-field activity was measured in a Plexiglas cage (height: $17 \mathrm{~cm}$, length: $30 \mathrm{~cm}$; width: $30 \mathrm{~cm}$ ) with black floor marked with white lines in $10 \mathrm{~cm}^{2}$ areas. Animals were randomly distributed into groups of eight animals. One hour after p.o. treatment with CEKb (1, $10,100$ and $1000 \mathrm{mg} / \mathrm{kg})$ or diazepam $(0,5 \mathrm{mg} / \mathrm{kg}$, i.p. $)$, each mouse was placed in the centre of the arena and its ambulation (peripheral and central area), immobility time, rearing, grooming and defecation were recorded for $5 \mathrm{~min}$ (De Lima, 2002). The number of grid lines crossed by both hind feet in a 5 min period was counted as an index of ambulation. After each trial, the openfield apparatus was wiped clean with ethanol (10\%) solution.

\section{Hole-board test}

The hole-board apparatus consisted of a Plexiglas cage (height: $15 \mathrm{~cm}$, length: $40 \mathrm{~cm}$; width: 40 $\mathrm{cm})$ with black floor marked with white lines limiting areas of $10 \mathrm{~cm}^{2}$. A total of 16 holes (diameter: $2.0 \mathrm{~cm}$ ) in equidistant position were arranged in the arena. Group of eight animals randomly distributed were used per dose. One hour after the CEKb administration (1, $10,100$ and $1000 \mathrm{mg} / \mathrm{kg}$, p.o. $)$, saline $(0.1 \mathrm{~mL} / 10 \mathrm{~g}$ body weight) or diazepam $(0,5 \mathrm{mg} / \mathrm{kg}$, i.p. $)$ each mouse was placed in the centre of the arena and its defecation, ambulation (peripheral and central area), rearing, 
grooming and head-dipping in the holes were recorded for $5 \mathrm{~min}$ (De Lima, 2002). After each trial, the holeboard apparatus was wiped clean with ethanol (10\%) solution.

\section{Rota-rod test}

Mice were placed on a rotating rod $(2.5 \mathrm{~cm}$ diameter divided in six equal compartments, rotating at $12 \mathrm{rpm}$ ). Animals remaining on the rod for $2 \mathrm{~min}$ in two successive trials were selected for testing $24 \mathrm{~h}$ before experiment. Groups of ten mice were treated with vehicle $(0.1 \mathrm{~mL} / 10 \mathrm{~g}$ body weight p.o.); $1,10,100$ or $1000 \mathrm{mg} / \mathrm{kg}$ of CEKb, p.o. or $0.5 \mathrm{mg} / \mathrm{kg}$ diazepam, i.p. Sixty minutes after the $\mathrm{CEKb}$ treatment, mice were placed on the spinning bar of the rota-rod apparatus for $1 \mathrm{~min}$. The time (s) spent on the rotating rod was recorded (De Lima, 2002).

\section{Elevated plus- maze test}

The elevated plus-maze (EPM) test has been widely validated to measure anxiety in rodents (Lister, 1987; 1990). The apparatus was set up of transparent Plexiglas and consists of a plus-shaped maze formed by two opposite open arms (length: $30 \mathrm{~cm}$; width: $5 \mathrm{~cm}$ ); crossed with two arms enclosed by walls (height: 15 $\mathrm{cm})$. Open and enclosed arms converge into a central platform $(5 \mathrm{~cm} \times 5 \mathrm{~cm})$. The maze is elevated at $40 \mathrm{~cm}$ from ground level by wood bearing and it is placed in a room illuminated with red light $(15 \mathrm{~W})$. Animals were randomly distributed into groups of ten mice. After 60 min of vehicle $(0.1 \mathrm{~mL} / 10 \mathrm{~g}$ body weight p.o. $)$; $\mathrm{CEKb}$ (1, 10 and $100 \mathrm{mg} / \mathrm{kg}$, p.o.); KbF-hex, KbF-Chlo, KbFaq and KbF-ethyl-ac $(0.1,1$ and $10 \mathrm{mg} / \mathrm{kg}$, p.o.) or diazepam $(0.5 \mathrm{mg} / \mathrm{kg}$ i.p. $)$ treatments, each animal was placed on the centre of the apparatus, facing one of the enclosed arm. The number of entries into and the time spent in open and closed arms, and the number of rears in a five minute period was noted. After each trial, the elevated plus-maze apparatus was wiped clean with ethanol (10\%) solution.

\section{Statistical analysis}

Results are expressed as mean $\pm \mathrm{SD}$, and statistical analysis of the data was performed by Dunn's Multiple Comparison test after Kruskal-Wallis nonparametric ANOVA using GraphPad Prism 5.0 software (GraphPad Software, Inc. CA. USA). Differences were considered to be statistically significant when $p<0.05$.

\section{Results and Discussion}

This study evaluated the anxiolytic-like effect of the hydro-ethanolic extract of the rhizomes of $K$. brevifolia Rottb., Cyperaceae, (CEKb), used in Paraguayan traditional medicine as a refreshing beverage, digestive, sedative and tonic. We tested the ambulatory (total, centre and peripheral) and emotional (rearing, grooming and defecation) behavior in the open-field test (Table 1) and the hole board, and motor coordination on rota-rod which were not modified at any doses of CEKb. Our results show that $K$. brevifolia, acutely administered, did not provoke ambulatory or emotional (rearing, grooming and defecation) changes in mice behavior neither hole board nor rota-rod (Figure 1). Diazepam was applied as anxiolytic positive control drug and no impairment in locomotion were observed at the dose used (Fisher \& Hughes, 1996).

In our study, pentobarbital-induced sleeping time in mice was significantly increased by oral administration of $10(p<0.01), 100(p<0.05)$ and 1000 $\mathrm{mg} / \mathrm{kg}(p<0.001)$ of $\mathrm{CEKb}$ and $10 \mathrm{mg} / \mathrm{kg}(p<0.05)$ of KbF-ethyl-ac (Figure 2). Pentobarbital-induced hypnosis latency was not significantly modified with any doses of $K$. brevifolia. This suggests that CEKB and $\mathrm{KbF}$-ethyl-ac could have a central nervous system depressant activity. It should be emphasized that the method employed for this assay is considered as a very sensitive way to denote agents with depressant activity on central nervous system (Carlini, 1973). It is possible that sedative effect recorded here could be related, among others, to an action on mechanism involved in sleep regulation, such as the interaction

Table 1. Effects of Kyllinga brevifolia (CEKb) on mice in the open file test.

\begin{tabular}{lccccc}
\hline \multirow{2}{*}{ Parameters } & Vehicle & \multicolumn{3}{c}{ CEKb (p.o.) } & \multicolumn{2}{c}{ Dz (i.p.) } \\
\cline { 3 - 6 } & & $1 \mathrm{mg} / \mathrm{kg}$ & $10 \mathrm{mg} / \mathrm{kg}$ & $100 \mathrm{mg} / \mathrm{kg}$ & $70.0 \pm 5.1$ \\
\hline Ambulation & $66.8 \pm 5.1$ & $69.3 \pm 7.8$ & $65.0 \pm 8.1$ & $\mathrm{mg} / \mathrm{kg}$ & $80.0 \pm 11.6^{*}$ \\
Immobility time (s) & $20.5 \pm 3.9$ & $16.8 \pm 4.3$ & $17.9 \pm 6.7$ & $15.9 \pm 2.8$ & $12.8 \pm 3.6^{*}$ \\
Rearing (number) & $34.0 \pm 4.0$ & $38.2 \pm 4.4$ & $29.3 \pm 4.7$ & $24.0 \pm 3.0$ & $23.5 \pm 2.9$ \\
Grooming (s) & $10.1 \pm 2.2$ & $9.5 \pm 3.6$ & $8.4 \pm 2.4$ & $9.5 \pm 1.6$ & $9.5 \pm 1.1$ \\
Defecation (number) & $1.2 \pm 0.5$ & $1.35 \pm 0.6$ & $1.8 \pm 0.6$ & $1.1 \pm 0.7$ & $1.5 \pm 0.5$ \\
\hline
\end{tabular}

Values are given as the mean $\pm \mathrm{SD} ; * p<0.05$ relative to the control group; Dunn's Multiple Comparison test after Kruskal-Wallis non-parametric ANOVA. 
with benzodiazepine binding site on GABAA receptor. However, false positive results due to pharmacokinetics interactions may appear, so ether induced-hypnosis should be perform to elucidate the influence of CEKB and KbF-ethyl-ac on central nervous system, and discard influences in barbiturate metabolism.

As depicted in Figure 3, oral treatment with 1,10 and $100 \mathrm{mg} / \mathrm{kg}$ of CEKb, significantly increased the percentage of entries $(p<0.05)$ and the percentage of time spent $(p<0.05)$ into the maze's open arms. A concomitant decrease in the percentage of time spent in the enclosed arms was also observed $(p<0.01)$. In the same way, oral administration of $0.1,1$ and $10 \mathrm{mg} /$ $\mathrm{kg}$ of KbF-ethyl-ac fraction significantly increased the percentage of entries $(p<0.01)$ and the percentage of time spent $(p<0.01)$ in the open arms of the EPM (Figure $4)$, and reduced the percentage of entrance $(p<0.01)$ and time spent $(p<0.01)$ in enclosed arms. Several plants inducing increasing exploration in open arms in the elevated plus-maze test are used to diminish anxiety in folk medicine. Among them Hydrocotyle umbellata (Rocha et al., 2011) and Aloysia polystachya (HellionIbarrola et al., 2005; Mora et al., 2005) were mentioned for South America. Furthermore, elevated plus-maze test is recognized as an useful tool to detect the effect of anxiolytic drugs (Hogg, 1996). These results were similar to those obtained with an anxiolytic dose of diazepam $(0.5 \mathrm{mg} / \mathrm{kg}, i . p$. $)$, the benzodiazepine used as a positive control in our study (Stock et al., 2000). To rule out the possibility of motor impairment that could influence the test, the animals were submitted to the rota-rod test and no motor impairment was detected.
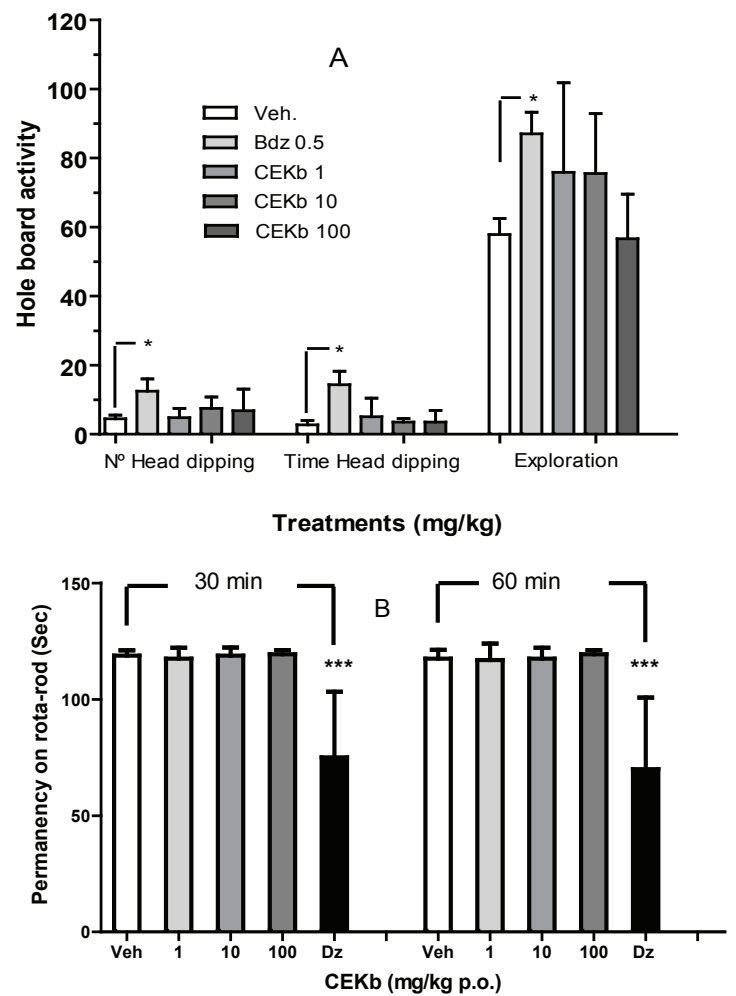

Figure 1. Effect of the vehicle (Veh, p.o.), diazepam (Dz, i.p.) and increasing oral doses of CEKb of Kyllinga brevifolia on hole-board (A) and rota-rod (B) test in mice. Each bar represents the mean $\pm \mathrm{SD}$ of eight (A) and ten animals (B). $*_{* *} p<0.001, * p<0.05$, significantly different from vehicle, Dunn's Multiple Comparison test after Kruskal-Wallis nonparametric ANOVA.
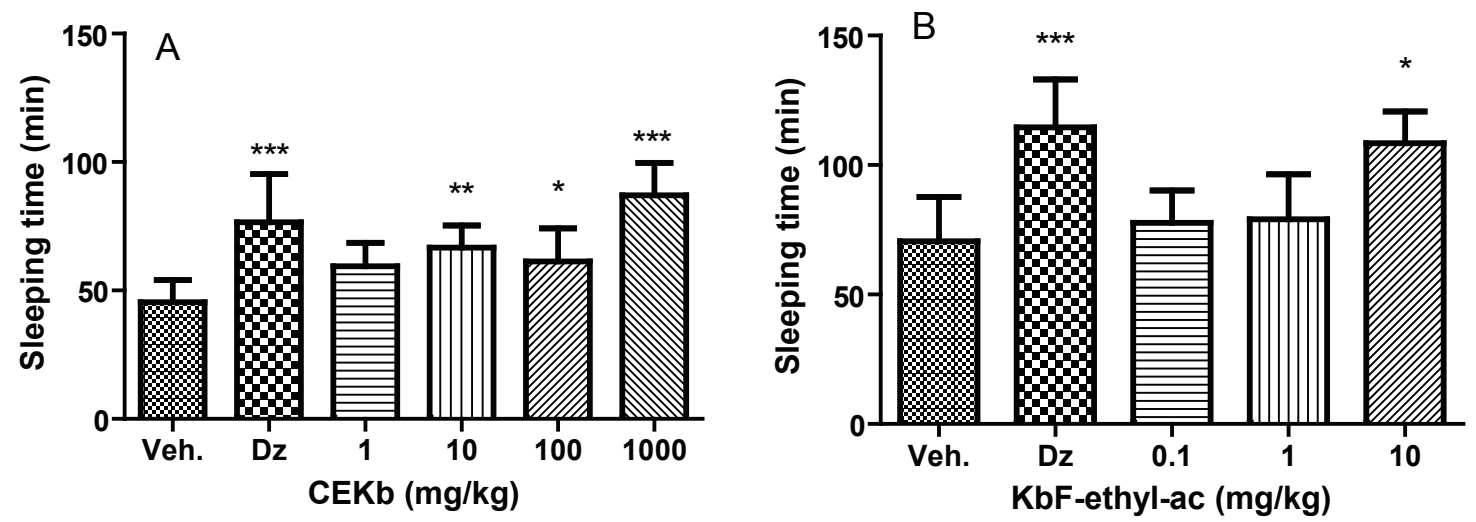

Figure 2. Effect of the vehicle (Veh, p.o.), diazepam (Dz, i.p.) and increasing oral doses of CEKb (A) and KbF-ethyl-ac (B) of Kyllinga brevifolia on the sleeping time induced by pentobarbital in mice. Each bar represents the mean $\pm \mathrm{SD}$ of twelve animals. ${ }^{* * *} p<0.001,{ }^{*} p<0.01 ;{ }^{*} p<0.05$, significantly different from vehicle, Dunn's Multiple Comparison test after Kruskal-Wallis non-parametric ANOVA. 

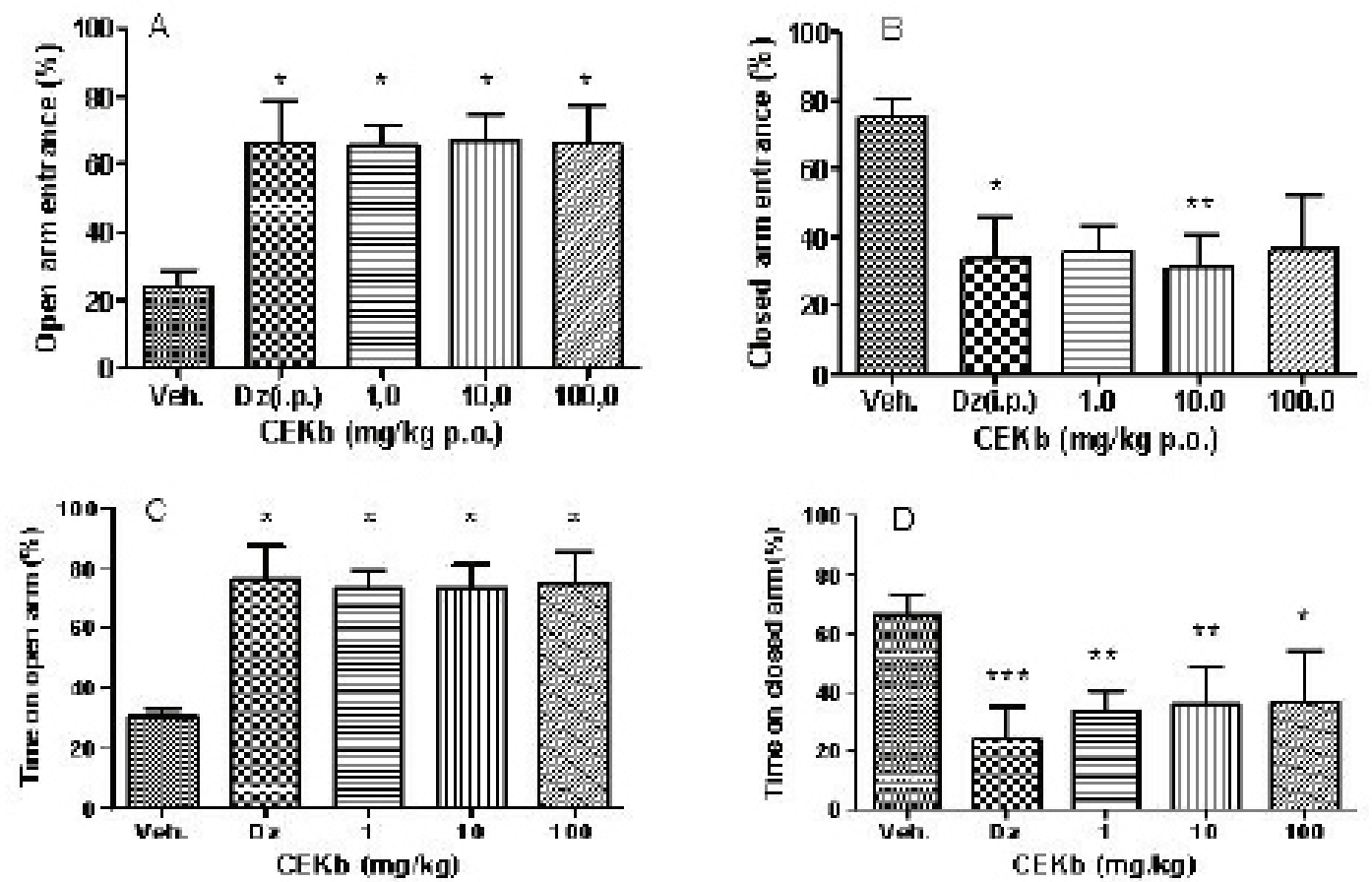

Figure 3. Behavioural performance of mice recorded over a 5 min session in the elevated plus maze $1 \mathrm{~h}$ after the administration of vehicle (Veh, p.o.), diazepam (Dz, i.p.) or CEKb of Kyllinga brevifolia (p.o.) Percentage of number of entries into the open arms (A), number of entries into the enclosed arms (B), time spent into the open arms (C) and time spent into the enclosed arms (D). Each bar represents the mean \pm SD of 10 animals. ${ }^{* * *} p<0.001,{ }^{* *} p<0.01 ;{ }^{*} p<0.05$, significantly different from vehicle, Dunn's Multiple Comparison test after Kruskal-Wallis non-parametric ANOVA.
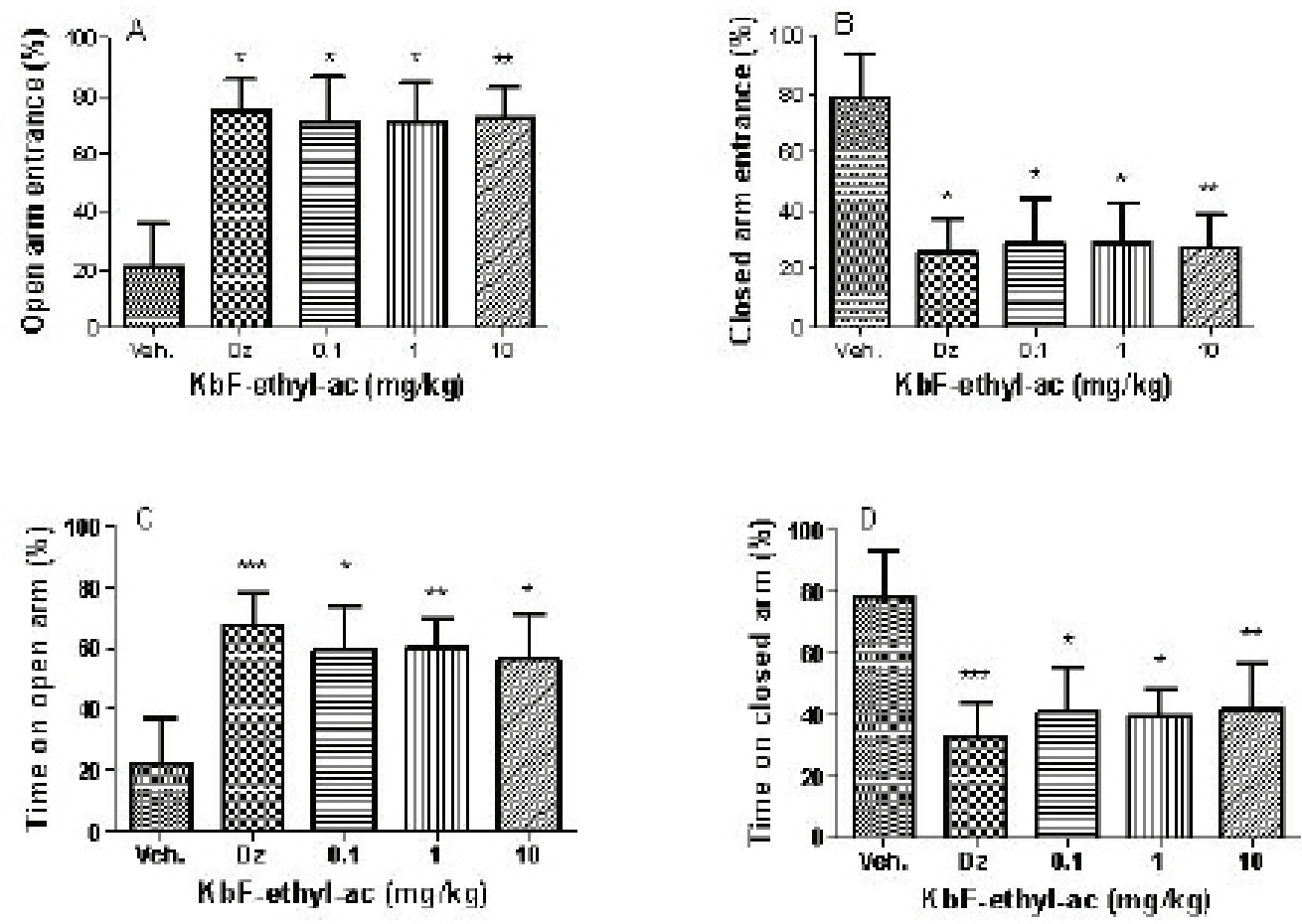

Figure 4. Behavioural performance of mice registered over 5 min session in the elevated plus maze $1 \mathrm{~h}$ after the administration of vehicle (Veh, p.o.), diazepam (Dz, i.p.) or oral doses of KbF-ethyl-ac from Kyllinga brevifolia. Percentage of number of entries into the open arms (A), number of entries into the enclosed arms (B), time spent into the open arms (C) and time spent into the enclosed arms (D). Each bar represents the mean \pm SD of ten animals. $* * * p<0.001 ; * * p<0.01 ; * p<0.05$ significantly different from vehicle, Dunn's Multiple Comparison test after Kruskal-Wallis non-parametric ANOVA. 
Inexperienced mice will usually prefer to spend much of their allotted time in the closed arms. This preference appears to reflect an aversion towards open arms, generated by fear to open space (Rodgers \& Dalvi, 1997).

It is relevant to note that other Cyperus species have shown effect on central nervous system. Thus, rhizome of $C$. rotundus and $C$. articulatus $\mathrm{L}$ have demonstrated effects that may be related to an allosteric modulation of GABAergic neurotransmission through benzodiazepine receptors (Rakotonirina et al., 2001, Bum et al., 2004). Our results show that CEKb exhibits sedative and anxiolytic-like effects, as claimed for $K$. brevifolia and the bioguided fractionation demonstrated that biological activity are in ethyl acetate fraction. Studies are underway to identify the active compounds of this plant, and to determine other more specific activities of Kyllinga brevifolia on the central nervous system. Apers et al. (2002) revealed the presence of flavonoids glycosides in $K$. brevifolia rhizomes; the existence of natural flavonoids possessing anxiolytic effect not associated with myorelaxant, amnestic or sedative actions has been demonstrated (Marder \& Paladini, 2002).

\section{Acknowledgments}

This work was performed under the financial support of Fondo Central de Investigaciones de la Universidad Nacional de Asunción, la Facultad de Ciencias Químicas and SECAB-CYTED (Secretaría Ejecutiva del Convenio Andrés Bello- programa CYTED CyT N ${ }^{\circ}$.1701(K1 2002)). We also want to thank to NAPRALERT for supporting us with bibliographical data.

\section{References}

Apers S, Huang Y, Van Miert S, Dommisse R, Berghe DV, Pieters L, Vlietinck A 2002. Characterisation of new oligoglycosidic compounds in two Chinese medicinal herbs. Phytochem Analysis 13: 202-206.

Basualdo I, Zardini EM 1995. Medicinal plants of Paraguay: underground organs II. Econ Bot 49: 387-394.

Bum EN, Lingenhoehl K, Rakotonirina A, Olpe HR, Schmutz M, Rakotonirina S 2004. Ions and amino acid analysis of Cyperus articulatus L. (Cyperaceae) extracts and the effects of the latter on oocytes expressing some receptors. J Ethnopharmacol 95: 303-309.

Carlini EA 1973. Farmacologia prática sem aparelhagem. Ed. Sarvier. São Paulo, p. 145-197.

De Lima TCM 2002. Evaluacion de la actividad y el comportamiento motor. In: Lapa AJ, Souccar C, LimaLandman MTR, Monteiro de Lima TC, eds., Métodos de Evaluación de la Actividad Farmacológica de
Plantas Medicinales. Editograf, CYTED/CNPq: Florianópolis, Brasil, p.76-78.

Ernst E, 2000. Herb-drug interactions: potentially important but woefully under-researched. Eur J Clin Pharmacol 56: 523-524.

Fisher CE, Hughes RN 1996. Effects of diazepam and cyclohexyladenosine on open-field behaviour in rats perinatally exposed to caffeine. Life Sci 58: 701-709.

Gatti C 1985. Enciclopedia guaraní-castellano de Ciencias Naturales y Conocimientos Paraguayos. Arte Nuevo Editores, Asunción, p.64.

Ha JH, Lee KY, Choi HC, Cho J, Kang BS, Lim JC, Lee DE 2002. Modulation of radioligand binding to the GABA(A)-benzodiazepine receptor complex by a new component from Cyperus rotundus. Biol Pharm Bull 25: 128-130.

Hellion-Ibarrola MC, Ibarrola DA, Montalbetti Y, Villalba D, Heinichen O, Ferro EA 1999. Acute toxicity and general pharmacological effect on central nervous system of the crude rhizome extract of Kyllinga brevifolia Rottb. J Ethnopharmacol 66: 271-276.

Hellion-Ibarrola M, Ibarrola DA, Montalbetti Y, Kennedy ML, Heinichen O, Campuzano M, Tortoriello J, Fernández S, Wasowski C, Marder M, De Lima TCM, Mora S 2005. The anxiolytic-like effect of Aloysia polystachya (Griseb.) Moldenke (Verbenaceae) in mice. J Ethnopharmacol 105: 400-408.

Hogg S 1996. A review of the validity and variability of the elevated plus-maze as an animal model of anxiety. Pharmacol Biochem Be 54: 21-30.

Lieb R, Becker E, Altamura C 2005. The epidemiology of generalized anxiety disorder in Europe. Eur Neuropsychopharm 15: 445-452.

Lister RG 1987. The use of the plus-maze to measure anxiety in the mouse. Psychopharmacology 92: 180-185.

Lister RG 1990. Ethologically-based animal models of anxiety disorders. Pharmacol Therapeut 46: 321-340.

Marder M, Paladini AC 2002. GABAA receptor ligands of flavonoid structure. Curr Top Med Chem 2: 847-861.

Mora S, Díaz-Véliz G, Millán R, Lungenstrass H, Quirós S, Coto-Morales T, Hellión-Ibarrola MC 2005. Anxiolytic and antidepressant-like effects of the hydroalcoholic extract from Aloysia polystachya in rats. Pharmacol Biochem Be 82: 373-378.

Pal D, Dutta S, Sarkar A 2009. Evaluation of CNS activities of ethanol extract of roots and rhizomes of Cyperus rotundus in mice. Acta Pol Pharm 66: 535-541.

RakotonirinaVS, Bum E N, Rakotonirina A 2001. Sedative properties of the decoction of the rhizome of Cyperus articulatus. Fitoterapia 71: 22-29.

Rocha FF, Almeida CS, Dos Santos RT, Santana SA, Costa EA, De Paula JR, Vanderlinde FA 2011. Anxiolyticlike and sedative effects of Hydrocotyle umbellata extract in mice. Rev Bras Farmacogn 21: 115-120.

Rodgers RJ, Dalvi A 1997. Anxiety, defense and the elevated 
plus-maze. Neurosci Biobehav R 21: 801-810.

Ross JB 2006. Drug therapy of depression and anxiety disorders. In: Brunton LL, Lazo JS, Parker KL, eds. Goodman \& Gilman's The Pharmacological Basis of Therapeutics. New York: McGraw Hill, p. 452-454.

Somasundaram A, Karthikeyan R, Velmurugan V, Dhandapani B, Raja M 2010. Evaluation of hepatoprotective activity of Kyllinga nemorales (Hutch and Dalz) rhizomes. J Ethnopharmacol 127: 555-557.

Stock H, Foradori C, Ford K, Wilson MA 2000. A lack of tolerance to the anxiolytic effects of diazepam on the plus-maze: a comparison of male and female mice. Psychopharmacology 147: 362-370.
Woods JH, Katz JL, Winger G 1992. Benzodiazepines: use, abuse and consequences. Pharmacol Rev 44: 151347.

\section{*Correspondence}

María del Carmen Hellión-Ibarrola

Facultad de Ciencias Químicas, Universidad Nacional de Asunción

Campus UNA, 2169. San Lorenzo, Paraguay

chellion@qui.una.py

Tel: + 59521585562

Fax: + 59521585564 